\title{
Development of a novel drug for uncomplicated malaria targeting the mitochondrial NADH: quinone oxidoreductase
}

\author{
Giancarlo A Biagini ${ }^{1 *}$, Alasdair Hill', Alison Mbekeani ${ }^{1}$, Alison Shone ${ }^{1}$, Gemma Nixon¹, Paul Stocks ${ }^{1}$, Peter Gibbons ${ }^{2}$, \\ Richard Amewu' ${ }^{2}$, David W Hong², Victoria Barton², Chandra Pidathala², James Chadwick², Louise Le Pensee², \\ Ashley Warman', Raman Sharma², Nick Fisher', Neil G Berry², Paul M O'Neill², Steve A Ward ${ }^{1}$
}

From Parasite to Prevention: Advances in the understanding of malaria

Edinburgh, UK. 20-22 October 2010

\begin{abstract}
NADH:quinone oxidoreductase (PfNDH2) represents a metabolic choke point in the respiratory chain of Plasmodium falciparum mitochondria and is the focus of a drug discovery programme. A miniaturised assay for recombinant PfNDH2 with robust assay performance measures was generated for the high throughput screening (HTS) of a focused library of 17,000 drug-like compounds. A quantitative structure-activity relationship has been developed around one of the chemical templates derived from the HTS hits. Lead molecules developed to date show selective inhibitory activity against PfNDH2 versus $P$. falciparum $\mathrm{bc}_{1}$ or dihydroorotate dehydrogenase (DHODH). Potent enzyme inhibition is accompanied by in vitro parasite kill of multidrug-resistant strains in the low $\mathrm{nM}$ range and clearance of parasites from in vivo P. berghei models. Lead molecules also display excellent in vitro therapeutic indices against human cell lines and bovine $b c 1$. Initial metabolic studies in human liver microsomes and hepatocytes indicate favourable pharmacology. These data support the further development of this new candidate drug targeting a novel parasite component.
\end{abstract}

\section{Author details}

'Liverpool School of Tropical Medicine, Pembroke Place, Liverpool, L3 5QA, UK. ${ }^{2}$ Department of Chemistry, Liverpool University, Pembroke Place, Liverpool, L3 5QA, UK

\section{Published: 20 October 2010}

\section{doi:10.1186/1475-2875-9-S2-04}

Cite this article as: Biagini et al.: Development of a novel drug for uncomplicated malaria targeting the mitochondrial NADH:quinone oxidoreductase. Malaria Journal 2010 9(Suppl 2):O4.

'Liverpool School of Tropical Medicine, Pembroke Place, Liverpool, L3 5QA, UK Full list of author information is available at the end of the article
Submit your next manuscript to BioMed Central and take full advantage of:

- Convenient online submission

- Thorough peer review

- No space constraints or color figure charges

- Immediate publication on acceptance

- Inclusion in PubMed, CAS, Scopus and Google Scholar

- Research which is freely available for redistribution

Submit your manuscript at www.biomedcentral.com/submit
() Biomed Central
C Biomed Central

(c) 2010 Biagini et al; licensee BioMed Central Ltd. This is an open access article distributed under the terms of the Creative Commons Attribution License (http://creativecommons.org/licenses/by/2.0), which permits unrestricted use, distribution, and reproduction in any medium, provided the original work is properly cited. 